Portland State University

PDXScholar

\title{
"Good For Rosetta" : The Fugitive Slave Law and the Case of Rosetta Armstead in Ohio, 1855
}

Alexandra A. Berg

Portland State University

Follow this and additional works at: https://pdxscholar.library.pdx.edu/honorstheses

Let us know how access to this document benefits you.

\section{Recommended Citation}

Berg, Alexandra A., "'Good For Rosetta" : The Fugitive Slave Law and the Case of Rosetta Armstead in Ohio, 1855" (2020). University Honors Theses. Paper 899.

https://doi.org/10.15760/honors.920

This Thesis is brought to you for free and open access. It has been accepted for inclusion in University Honors Theses by an authorized administrator of PDXScholar. Please contact us if we can make this document more accessible: pdxscholar@pdx.edu. 


\section{"Good For Rosetta": The Fugitive Slave Law and the Case of Rosetta Armstead in Ohio, 1855}

\section{By}

Alexandra A Berg

An undergraduate honors thesis submitted in partial fulfillment of the requirements for a degree of Bachelor of Arts

In

University Honors

And

History

Thesis Advisor

Professor Patricia Schechter

Portland State University

2020

Approval 
The thesis of Alexandra Berg for Bachelor of Arts with Honors in History was presented May 28th, 2020 and accepted by the thesis committee and the department.

Committee Approvals:

1)

2)

Department Approvals:

1) 
Rosetta Armstead was a sixteen-year-old enslaved girl who in March of 1855 was being transported through the state of Ohio on her way to Kentucky, where she was to become the nurse to her owner's infant child. While overnighting in Columbus she came to the attention of local abolitionists and her case was brought in front of the Ohio courts. Her whirlwind case challenged the Fugitive Slave Law of 1850 as well as the authority of the federal government when her freedom was granted by the power of Ohio's state courts. Her case highlights key issues in the 1850's political crisis around slavery and states rights, issues which would eventually ignite the Civil War. The fracture points around power, and the tensions between North and South, federal and state authority, were all brought up in the contentious decision which freed Rosetta from bondage. 


\section{"Good For Rosetta": The Fugitive Slave Law and the Case of Rosetta Armstead in Ohio, 1855}

\section{Table of Contents:}

Introduction...........pg. 5

Chapter 1: The Fugitive Slave Law and the Struggle over Regional Legitimacy.........pg. 10

Chapter 2: Personal Liberty Politics, Pro-slavery Laws, and the Underground Railroad in Ohio.....pg. 19

Chapter 3: The Story of Rosetta..........pg. 30

Conclusion: Rosetta Beyond the Question of Slave, Fugitive or Free.......pg. 42

Bibliography..........pg. 48 


\section{Introduction:}

In March of 1855, a sixteen-year-old enslaved girl named Rosetta Armstead was being transported by Dr. Miller, a friend of her owner Dr. Dennison, through Ohio en route to Kentucky. Formerly the property of the recently deceased President Taylor, she had been gifted to his daughter's family upon his death. Dr. Dennison, Rosetta's new owner, was a protestant episcopal preacher and a wealthy slave owner in Louisville, Kentucky. ${ }^{1}$ However, while overnighting in Columbus Rosetta's presence came to the attention of some local abolitionists, who quickly rallied around her. Rosetta would go on to appear before two Ohio court judges, who were both keen to further their agenda of affirming the authority of Ohio's state laws by declaring that Rosetta was not in fact a fugitive, never having technically run away, and was therefor not eligible to be tried under the Fugitive Slave Law. Despite this fact, Rosetta's case occurs firmly within the context of the fugitive slave issue, as it was expressly used to challenge the Fugitive Slave Law and the southern right of recapture. Rosetta's case is a flash point in the long standing contention over slavery between North and South, revealing in the heated debates around her the issues of power, of state sovereignty versus federal authority, which were deeply embedded within the issue of fugitive slaves.

Rosetta's story is a whirlwind event, as almost within a single month she went from bondage to freedom. However, though her story was fairly widely discussed while it was happening, showing up in local as well as national newspapers, as soon as the dust had cleared, Rosetta Armstead passed back into obscurity. Her story, as far as the historical archive is concerned, begins and ends with her introduction to the Ohio court system, the abolitionist cause, and the laws both local and national surrounding fugitive slaves. Rosetta's voice is buried under the voices of the powerful white men around her, who were not only privileged at the time but who are also privileged in the historical

\footnotetext{
${ }^{1} \mathrm{~J}$. Blaine Hudson, Fugitive Slaves and the Underground Railroad in the Kentucky Borderlands(North Carolina: McFarland and Company, Inc., 2006), pg. 141-143
} 
narrative. ${ }^{2}$ Unburying Rosetta's voice is a delicate excavation process, and one which can only be partially accomplished within the confines of this paper. She appears only when her body can be made into a challenge to the enforcement of the Fugitive Slave Law, mostly by the white men around her. She does not appear as a person outside of her own case, and within her case she is rarely seen as a somebody beyond her contended identity of slave or free. Therefor, what follows is a story about a girl named Rosetta Armstead, but it is also a story around her.

In other words, there are two stories being told here. One story is the tale of a sixteen-year-old girl escaping slavery by going from a slave state to a free state and therefore becoming a catalyst for issues concerning slavery and fugitives thereof, the other is a story of political power. Rosetta Armstead is the central figure, yet her story as it as been inscribed by the historical archive represents all the ways in which a girl of color can be seen and yet not seen by the state, and serves as a study of the intricacies of agency and who has it and who doesn't. ${ }^{3}$ Out of the thirty-three news articles and seven court documents I found, Rosetta's voice is never once heard directly. Kimberle Crenshaw, with her vital work on intersectionality, provides a framework through which we can better understand this question. Rosetta faced her experience in the Ohio court system not only as a slave but as a young girl as well. However, the court transcripts make almost no special note of her gender. They only care about her identity as a slave who can be brought into freedom and therefor challenge the enforcement of the Fugitive Slave Law. ${ }^{4}$ The newspapers, on the other hand, focused much more explicitly on her identity as a girl, with a lengthy article in the Belmont Chronicle making a particular fuss

\footnotetext{
${ }^{2}$ Deborah Gray White, Ar'n't I a Women? Female Slaves in the Plantation South, Revised edition (New York: W. W. Norton and Company, 1999)

3 Tom Calarco, The Search for the Underground Railroad in South Central Ohio (Charleston, South Carolina: The History Press, 2018) ch. 1; Jonathan Daniel Wells, Blind No More: African American Resistance, Free Soil Politics, and the Coming of the Civil War (Athens, Georgia: The University of Georgia Press, 2019)

${ }^{4}$ Kimberle Crenshaw "Demarginalizing the Intersection of Race and Sex: A Black Feminist Critique of Antidiscrimination Doctrine, Feminist Theory and Antiracist Politics." University of Chicago Legal Forum: vol. 1989: Iss. 1, Article 8
} 
about her gender while reporting on her initial arrest. ${ }^{5}$ However, if we wish to uncover her agency, we must understand that her experience was shaped by both of these identities simultaneously. By considering the ways in which the legal system and the political and social structure expected her to act a certain way as a slave and as a girl of color, we can hopefully begin to see the ways in which she might have navigated around these structures, thereby asserting agency. Through circumstances more or less out of her control Rosetta was able to win her freedom, but in the process her case served as an opportunity for several interlocking political issues to be further articulated, mostly by powerful free white men who arranged themselves ideologically and politically on opposite sides of the slavery issue. Slavery, of course, is tied to the rising national political crisis of the 1850s between North and South. A struggle which finds its axis point around slavery but which can really be understand as a struggle over power. The question of how the federal government should regulate slavery, whether it should be allowed to spread into recently acquired states or if it should be contained to the South, was also a struggle over legitimacy. The legitimacy of the North versus the South and of the states versus the federal government. ${ }^{6}$

Though I will ground this discussion in political and legal terms, I wish to give equal weight to the individuals involved. I hold that history cannot be fixed into a neat pattern but is the product of complex and intersecting variables, and equal weight must be given to the power of legal and political institutions as well as the individuals who are working within or against those institutions. Joseph C Miller, in his book The Problem of Slavery as History, provides the basis for the framework I wish to apply here. He states that institutions and societies are not actors, but are instead the vehicles through which

\footnotetext{
${ }^{5}$ Belmont Chronicle, March 29th, 1855, pg. 2 (The newspapers cited in this paper are mostly four-page sheets whose internal pages have been hand-numbered by archivists. When possible, I use this added page numbering for ease of later reference by modern readers) ${ }^{6}$ Anthony Gregory, The Power of Habeas Corpus in America: From the King's Prerogative to the War on Terror (Oakland, California: the Independent Institute, 2013) introduction; Tom Calarco, The Search for the Underground Railroad in South Central Ohio (Charleston, South Carolina: The History Press, 2018) ; Jonathan Daniel Wells, Blind No More: African American Resistance, Free Soil Politics, and the Coming of the Civil War (Athens, Georgia: The University of Georgia Press, 2019) ch. 2
} 
motivated human actions take shape. Woven in and around the story of a nation and a society torn over the institution of slavery are many threads representing people who had varying stakes in these issues: free and enslaved African Americans, clergy, proand anti-slavery activists, and politicians and lawyers of varying political stripes, ideological commitments, and opportunistic tendencies. It was not the law that freed Rosetta Armstead, but individuals with complex motivations who saw an opportunity to free a girl from slavery and consequently further their own agendas. The specific laws and political structures which Rosetta encountered are not the engines of her story, but rather the context within which her story takes place. ${ }^{7}$

If I was to only present the facts of Rosetta's case, and simply state the play by play of how she won her freedom, it might read as a comforting story of the triumph of freedom in the United States of America. A girl, surrounded by heroic saviors who come to her aid, succeeds against all odds. But as soon as I were to begin comparing Rosetta's case to similar examples in the history of fugitive slaves, any reader would be able to point out the seemingly arbitrary nature of which cases were successful and which ones were not. This is why it is so important to place these cases in their larger political context while maintaining an emphasis on individual human action. Rather than fixing history within a neat and ordered pattern, the choices and circumstances of individuals within the context of their political and social situation must be reckoned with.

Every step in Rosetta's story reveals something about the larger scope of slavery and the struggles that were arising around the issue of fugitive slaves and the Fugitive Slave Law. Therefore, I have chosen to ground Rosetta's story in an in-depth discussion of the Fugitive Slave Law and its attendant issues, in order to provide a well articulated and dynamic account. Rosetta's story can be seen through a national framework that places it as a point of friction within the political context of the Fugitive Slave Law. This lense necessitates a deeper look at the political and legal functions of the Law in order to understand the large scale, national issues which were shaping events around

\footnotetext{
7 Joseph C Miller, The Problem of Slavery as History, (New Hampshire, CT: Yale University Press, 2012) pg. 8
} 
Rosetta. Therefor the first section will serve to 'set the stage', by addressing national and state politics surrounding the issue of fugitive slaves.

The other lense is a more interpersonal lense that focuses on the people directly around Rosetta. This paper examines the specific attitudes in Ohio, of the abolitionists who aided her and the marshal who kidnapped her and the ruling of the judge that she appeared before. Such a lense requires an understanding of Ohio's complex relationship with slavery and race and how its place as a border state in this issue made it an active part of the Underground Railroad and abolition work as well as a home of pro-slavery resistance. Thus the second section will address local abolition work and the Underground Railroad. Finally a third section will take a deep dive into Rosetta's case, discussing its details within the context of similar cases in order to understand how it fits within the larger issues of sections one and two.

As I will discuss in this paper, even when Ohio passed laws against the Fugitive Slave Law, they cannot be seen as purely altruistic measures meant to protect African Americans out of the goodness of the white abolition cause. In the instance of Rosetta, a complex cast of characters became invested in her case because they saw a chance to further their own interests, which were themselves tied into larger issues driven on a national stage by a vast array of actors. However, understanding that not all actors have equal agency, and that some like Rosetta had to find ways to express agency within the constrictions of race, gender, and bondage is another theme which I hope to draw through this story. Rosetta's case reveals how a nation's legal system, like its political system, doesn't serve a higher law but rather the individuals and causes which have the power to wield them. Even when circumstances align to free a teenaged girl from slavery, as we shall see in Ohio, the laws responsible are not moral engines serving a just cause. Instead, they function primarily as an expression of power.

I have made the decision to use the term 'African American' to refer to both free and enslaved individuals at the time who claimed descent from Africa. When applicable, I will use the terms 'black' and 'white' when discussing the racist ideology that was embedded within both the North and South at this time, and which influenced people's 
approach to slavery and abolition. I will use the term 'fugitive' to refer to individuals who were in the process of escaping from slavery when discussing their case. It is not meant to infer any criminal association but rather to infer their relationship with the law.

\section{Chapter 1:}




\section{The Fugitive Slave Law and the Struggle over Regional Legitimacy}

By the turn of the century, tensions were rising between the North and the South. At issue was slavery. From a distance, it is easy to mistake this contention as a purely moral struggle, but a closer look will quickly reveal its material grounding in the issue of property. Specifically the property right of southern plantation owners to own slaves against growing northern objections against slavery. In the halls of congress, politicians debated fiercely over the Mississippi Compromise, the Annexation of Texas, The Wilmont Proviso and the duty of the federal government to protect the southern institution of slavery. ${ }^{8}$ On the street, people passed out pamphlets, attended voluntary organizations, and discussed these issues in their churches. Both sides saw the other as a looming threat to what they saw as the 'proper' order of law, and the issue of slavery, whether or not it would be allowed to spread into new territories and whether the North would be forced to support the South's interests, was beginning to build to a boiling point. ${ }^{9}$

Arguments about religion and morality, and what they had to say in regards to slavery, were certainly powerful influencers on both sides of the divide. Abolitionists such as Theodore D. Weld and Angelina and Sarah Grimké published books, pamphlets and gave lectures on the sinfulness of slavery and called out to the divine nature of human rights to protest the institution. Southerners at the same time were quick to point out the numerous mentions of slavery in the Bible, using it to point out its moral and civilized nature. ${ }^{10}$ Senator Robert M. T. Hunter of Virginia said, "there is not a

\footnotetext{
${ }^{8}$ Steven Lubet, Fugitive Justice: Runaways, Rescuers, and Slavery on Trial (Cambridge, MA: Harvard University Press, 2010) pg. 37

${ }^{9}$ Henry Mayer, All On Fire: William Lloyd Garrison and the Abolition of Slavery (New York: W. W. Norton and Company, 2008); Tom Calarco, The Search for the Underground Railroad, ch. 1 ${ }^{10}$ Wilfred Carsel "The Slaveholders' Indictment of Northern Wage Slavery" The Journal of Southern History, vol. 6, no. 4 (November, 1940), pg. 504-520; Caroline L. Shanks "The Biblical Anti-Slavery Argument of the Decade 1830-1840" The Journal of Negro History, vol. 16, no. 2 (April, 1931), pg. 132-157
} 
respectable system of civilization known to history whose foundations were not laid in the institution of domestic slavery."11 However such arguments should not be overstated. Though there were strong moral outcries both for and against slavery the issue primarily revolved around the question of power and rights.

It was primarily the fear that the political apparatus would sway out of their favor that drove both the North and the South to articulate their opinions on slavery, pushing for laws that would protect their interests. Since the very founding of the Nation itself, it was clear that the issue of fugitive slaves would remain as contentious or maybe even more so than the institution of slavery itself. ${ }^{12}$ The root of the issue lay in the Constitution, which held a special clause guaranteeing not only the right to own slaves, but also mandating to a certain extent that fugitive slaves be returned to their owners at all costs.

No Persons held to Service or Labour in one State, under the Laws thereof, escaping into another, shall, in Consequence of any law or Regulation therein, be discharged from such Service or labour, But shall be delivered up on Claim or the party to whom Service or Labour may be due. ${ }^{13}$

At the time that the Constitution was being written, slavery was not only widespread throughout the North and South, but it was also relatively profitable. Almost all of the founding fathers owned slaves of their own, and only very few ever actively opposed it. (Among those who did were Benjamin Franklin and Alexander Hamilton) ${ }^{14}$

\footnotetext{
${ }^{11}$ Steven Lubet, Fugitive Justice, pg. 38

12 Thomas D Morris, Free Men All: The Personal Liberty Laws of the North, 1780-1861

(Baltimore: John Hopkins University Press, 1974); "A Century of Law Making for a New Nation: U.S. Congressional Documents and Debates, 1774-1875” American Memory: The Library of Congress accessed May 19th, 2020, http://memory.loc.gov/cgibin/ampage?collld=Ilac\&fileName=003/llac003.db\&recNum=702; "To Pass S. 42, An Act Respecting Fugitives From Justice and Persons Escaping From The Service of Their Masters." GovTrack, accessed May 19th, 2020, https://www.govtrack.us/congress/votes/2-2/h85

13 "Article IV, Section 2: Movement of Persons Throughout the Union" Interactive Constitution, accessed may 19th, 2020, https://constitutioncenter.org/interactiveconstitution/interpretation/article-iv/clauses/37

${ }^{14}$ Steven Lubet, Fugitive Justice, pg. 12
} 
Despite this, many southerners began to see a conspiracy of sorts forming in the North, seeking to undermine what was an essential aspect of their society, and began to demand that something be down to protect them. Cloaked in the language of property rights, it was also about upholding the Union as well as the status quo of a nation which had grown up with the institution of slavery. ${ }^{15}$ Any fugitive case seemed, in the eyes of the South and the pro-slavery North, to challenge the rule of law. ${ }^{16}$ The South was very adamant that they had a constitutional right to own slaves. A privilege which was granted to them through the highest laws of the Nation, and were prompt to point this out any time their right was challenged. ${ }^{17}$ In 1772 a British decision in the case Somerset $V$. Stewart, which released a runaway Virginia slave, seemed to affirm these fears. ${ }^{18}$ In 1788, the case of an African American man by the name of John Davis, who had been living freely under Pennsylvania's state laws but was still considered a slave in Virginia, made its way all the way up to the executive branch when President Washington was asked to weigh in on the subject. ${ }^{19}$

Eventually the political discussion around the issue of fugitive slaves led to the creation of the Fugitive Slave Law of 1793. This law strengthened the Fugitive Slave Clause by adding explicit fines should the retrieval of a fugitive be obstructed as well as giving the judge or magistrate in question the power to confirm the identity of the fugitive without question. ${ }^{20}$ Though it did give slave owners considerable legal clout in this regard, it was very quickly revealed to be toothless. The punishment for hindering the recapture of a fugitive was a minor fine, and southerners would eventually attack the law as being inefficient at protecting their constitutional right to own slaves. ${ }^{21}$ Though the issue of fugitive slaves came up a few times in the intervening years, it wasn't until 1850 that another bill was successfully introduced on the federal level.

\footnotetext{
${ }^{15}$ Steven Lubet, Fugitive Justice, pg. 11-22

${ }^{16} \mathrm{lbid}$, pg. 37-49

17 Ibid, pg. 39; Anthony Gregory, The Power of Habeas Corpus, pg. 79

18 Somerset V. Stewart (1772) 98 ER 499

19 "Fugitive Slaves: Fugitives From Labor" National Archives, accessed May 19th, 2020, https://www.archives.gov/education/lessons/fugitive-slaves.html

${ }^{20}$ Steven Lubet, Fugitive Justice, pg. 21

${ }^{21}$ Thomas D Morris, Free Men All, ch. 8
} 
It is important to remember that if it were not for the shear number of slaves which escaped from the South on a regular basis, there would have been no need for this issue to be revisited. As it was, the South was growing impatient with the lack of results from the 1793 Fugitive Slave Law. Arthur Butler, a senator from South Carolina, reckoned that the border states lost as much as $\$ 200,000$ from runaway slaves every year. ${ }^{22}$ While it is impossible to definitively say how many slaves were escaping every year, since the records are shoddy at best, it is clear that the peculiar institution of the South was draining resources faster than a sieve drains water. ${ }^{23}$ In fact, some scholars claim that slavery was becoming so unprofitable in the 19th century that the only way it could function was if the federal government helped to "socialize" the costs of maintaining it. ${ }^{24}$ While the Fugitive Slave Law of 1793 was supposed to address this problem, by the mid 19th century, it was clear to southern politicians that the law was not up to the task. Senator James Mason of Virginia declared that the only way to stop the problem of runaway slaves and give plantation owners the tools they needed to properly retrieve them was to enact a law with teeth. ${ }^{25}$

On January 29, 1850, Senator Henry Clay introduced a resolution calling for a stronger Fugitive Slave law. His call was picked up by Senator Mason and oddly enough, Senator Daniel Webster, who until then had been known as a relatively anti

\footnotetext{
22 R. J. M. Blackett, The Captive's Quest For Freedom: Fugitive Slaves, the 1850 Fugitive Slave Law and the Politics of Slavery (Cambridge University Press, 2018), pg. 5

${ }^{23}$ After the passage of the initial fugitive slave law in 1793, the issue of fugitive slaves was brought again up in 1817. A bill was proposed by a special House committee, which had been assigned to consider how to better provide for the recapture of fugitives. On December 29th they introduced an amendment to the act of 1793 which would have completely cemented the act as a proslavery law. This amendment proposed that the only proof required to claim an individual as a runaway slave was to show a certificate provided by a judge or magistrate from the state from which the individual was claimed to have escaped. Such a law would clearly subordinate northern states to their southern brethren, strong arming them into supporting the recapture of fugitives and by extension the institution of slavery. Opponents of slavery in the north immediately attacked this proposed bill, focusing on an issue that would become a mainstay of the fugitive debate, the writ of habeas corpus. Essentially, the right to be represented in court.

24 Anthony Gregory, The Power of Habeas Corpus, pg. 79

${ }^{25}$ R. J. M. Blackett, Quest for Freedom, pg. 7
} 
slavery Whig politician from Massachusetts. ${ }^{26}$ They proposed a way to not only insure the return of fugitive slaves, but also a return to the rule of law and unity between North and South. ${ }^{27}$ The bill fiercely strengthened penalties as well as providing more freedom and authority for commissioners tasked with returning fugitives. Nine long months would be spent on debating the question of fugitives before the bill would be passed into law in August of 1850 . The South claimed this law as the ultimate test of the North's commitment to unity, and the least that they could be expected to do if they wished to uphold what the South saw as a constitutional right to own slaves. The North on the other hand cried that it threatened key pillars of law, the right of trial and habeas corpus most importantly, and bound the federal government to the interests of southern slave owners in an unjust distribution of power. ${ }^{28}$

According to Steven Lubet, the author of Fugitive Justice: Runaways, Rescuers, and Slavery on Trial, the compromise of 1850 ended up being the achilles heel of slavery. "It transferred the controversy from remote, and barely settled, territories to the population centers of the East, potentially entangling the federal government in every escape, warrant, seizures, rescue, and trial until the advent of the Civil War."29 More importantly, the compromise had failed to anticipate the backlash it would receive not only from white northerners but from free African Americans as well. By creating a law

\footnotetext{
${ }^{26}$ Steven Lubet, Fugitive Justice, pg. 40

27 This emphasis on unity was another common oratory tactic of pro-slavery advocates, who called upon people's desire for peace and prosperity when pointing out the agitating actions of abolitionists.

${ }^{28}$ Steven Lubet, Fugitive Justice; R. J. M. Blackett, Making Freedom: The Underground Railroad and the Politics of Slavery (Chapel Hill, NC: University of North Carolina Press, 2013) pg. 32-67; National debates around the issue of fugitives clearly showed that the federal government was swaying dangerously close to becoming a tool of the southern slave owning interests. The South had the benefit of a much more unified front, which along with a few key supporters in the North such as Senator Daniel Webster of Massachusetts, were better situated to propose bills on a federal level. In response, many northern abolitionists called upon an even higher law, citing a divine and enlightened view on human rights to support the authority of local laws which conflicted with the constitutional approval of slavery. Others took a more extreme stance and criticized the constitution itself, claiming that no document which upheld slavery should be considered untouchable. William Lloyd Garrison went so far as to burn a copy of it in a park during a Fourth of July celebration.

${ }^{29}$ Steven Lubet, Fugitive Justice, pg. 49
} 
that was so invasive in the lives of everyday people, abolitionists basically had their ammunition handed to them for their fight against slavery. ${ }^{30}$

According to northern opponents, the law provided an unfair financial incentive in favor of slavery, as it promised $\$ 10$ for every slave brought in but only $\$ 5$ if the fugitive was released, paid through the federal treasury. One of the very first fugitive slave cases to be tried under the Fugitive Slave Law cost the federal government $\$ 263.91 .^{31} \mathrm{It}$ also conscripted otherwise uninvolved citizens into the service of the slave holding South. From those who were ambivalent about slavery to those who were outright against it, if called upon to aid in the capture of a fugitive, a citizen of the United States could no longer legally refuse. Standing by and doing nothing, though not necessarily an act of resistance towards the institution of slavery in and of itself, was enough to be interpreted as the 'aiding and abetting' of fugitives. The case of Castner Hanway, where a white man was brought to trial for treason because he refused to aid in the capture of a fugitive, is a perfect example of how easy it could be for a person to be called a traitor to his nation, simply for doing nothing. Despite the fact that Castner Hanway made no active move to block the capture of the fugitive, it was enough to land him in jail, though he was acquitted of the charges of treason. ${ }^{32}$

The Fugitive Slave Law also undermined the power of habeas corpus, a writ which played a central role in multiple fugitive slave cases, including Rosetta's. Anthony Gregory, in his book The Power of Habeas Corpus in America: From the King's Prerogative to the War on Terror, describes the writ as one which has been held up to an almost mythic status in the history of anglo-America, but which fails to hold up to its promise of grandeur under closer inspection. It is both less and more powerful than assumed. If its primary purpose is to ensure against illegal custody and to give a kind of checking power to state courts against executive or federal power, then Gregory claims

\footnotetext{
${ }^{30}$ Ibid, pg. 49

${ }^{31}$ R. J. M. Blackett, Making Freedom, pg. 36

${ }^{32}$ Member Of The Philadelphia Bar. A history of the trial of Castner Hanway and others, for treason, at Philadelphia in November, . With an introduction upon the history of the slave question. Philadelphia, U. Hunt \& sons, 1852. Pdf. https://www.loc.gov/item/44019568/.
} 
that it more often than not fails. Despite this, the writ of Habeas Corpus became a central issue in the following years whenever the Fugitive Slave Law came under discussion, as it was used equally by North and South to both support and obstruct slavery. ${ }^{33}$ According to Gregory, since its use in specific cases can show the ebb and flow of power between them, its use has a much to do with authority and power as it has to do with liberation. ${ }^{34}$

Southerners, of course, wished to suspend the writ in cases of fugitives, arguing that it was not within the right of any northern judge to determine whether an individual be free or enslaved as long as the claimant could provide sufficient proof that the individual in question belonged to them. Essentially, the hope was that the Fugitive Slave Law would make it so that there was no way to bring a fugitive slave case in front of a northern judge. Northerners, on the other hand, fiercely tried to protect the right of all people, even fugitives, to the writ. A select committee of the Ohio Legislature made by Leicester King produced a report that claimed that Habeas Corpus was extended to all persons, whether citizen or alien, though the Judiciary Committee claimed almost exactly the opposite. According to them, the states had no power to demand a trial by jury and other such writs when the Fugitive Slave Law explicitly said that the fugitive "shall be delivered up on claim."35

The true transgression of the Fugitive Slave Law, however, was its ability to interfere, in an incredibly destructive manner, in the lives of African Americans, enslaved and free alike. Those slaves who were attempting to find freedom encountered the law as one stumbling block amongst many. It gave power to those who already had an impressive advantage by legalizing the 'no holds bared' attitude of slave catchers. ${ }^{36}$ In one highly publicized case in Ohio, a white abolitionists, Sheriff Layton, who had come to the aid of the fugitive Addison White, was beaten by a pro-slavery

\footnotetext{
${ }^{33}$ Anthony Gregory, The Power of Habeas Corpus, pg. 78

34 Ibid, Intro and pg. 84; Prigg v. Pennsylvania, 41 U.S. 16 pet. 539539 (1842)

35 Hyun Hur, "Radical Antislavery and Personal Liberty Laws in Antebellum Ohio, 1803-1857" (Phd dissertation, University of Wisconsin-Madison, 2012) pg. 77-78

${ }^{36}$ Thomas D Morris, Free Men All, ch. 1
} 
mob in the process. Not only were those responsible for the beating found innocent, but Sheriff Layton was found guilty under the Fugitive Slave Law. ${ }^{37}$ What under other circumstances would have been violent gangs of kidnappers became dutiful agents of the law. There was no course of action which fugitive slaves could take, not even self defense, which would not be seen as criminal under the light of the law. ${ }^{38}$ Conversely, no atrocity was too extreme when committed in the name of retrieving errant slaves.

The law also required that only a certificate of ownership, to be acquired by a magistrate or some other legal authority in the state from which the slave had escaped, be presented and that once the commissioner had such proof that the fugitive in question was in fact a slave, no court in the United States could nay say that certificate. Senator Mason of Virginia claimed that this was necessary not only because the Constitution promised a "speedy redress" of any loss of property but also insured that no one had "a right to interpose between the claimant and the fugitive, or to inquire whether the slave be his, or whether he is a slave at all, far less to molest or hinder him in the capture." ${ }^{39}$

Another way in which the law was incredibly invasive was its ability to affect the lives of free African Americans. The issue of free African Americans being made vulnerable to capture was one of the biggest concerns for white northerners. Even those who had no intention of defying slavery spoke out against the idea that free denizens of their states could be taken without proper legal protections and brought into slavery..$^{40}$ In all northern states, free African Americans were required to carry with them certificates of freedom. While these papers obviously meant a great deal to them, they could also readily be ignored by zealous commissioners eager to sell kidnapped free African Americans into slavery. Southerners were more then happy to hire agents to roam northern cities and farmsteads incognito waiting to 'recognize' a fugitive from slavery.

37 Tom Calarco, Search for the Underground Railroad, pg. 122

${ }^{38}$ Samuel May, The Fugitive Slave Law and Its Victims, (Cambridge, MA: Harvard University, 1861)

39 Thomas D Morris, Free Men All, pg. 132; R. J. M. Blackett, The Captive's Quest for Freedom, pg. 10

${ }^{40}$ R. J. M. Blackett, The Captive's Quest for Freedom, pg. 8 
Gangs like the Patty Cannon gang were a lot less subtle about their actions, and made a business of kidnapping African Americans, mostly children, and selling them across the border from Delaware into Maryland. Once in the South, kidnapped African Americans could be sold a number of times in rapid succession in order to muddy the trail and thus very few ever returned to freedom. ${ }^{41}$ Thus the Law was a tool built to support the southern right to recapture, erase the ability of African Americans to resist, and ignore the right of northerners to protest slavery.

\section{Chapter 2: \\ Personal Liberty Politics, Pro-slavery Laws, and the Underground Railroad in Ohio}

The North is often remembered as a bastion of liberty during the Antebellum and Civil War period. It fought on the side of good and resisted the evils of slavery. However, the North was not always unified in its opposition to slavery, and northern states made actions to support slavery just as often as they opposed it. States physically removed from the issue such as Vermont and Massachusetts often took a clearer moral stance against slavery, while border states like Ohio, which had more direct contact with slavery, often had a more active discord around the issue. In order to truly understand how conflicted Ohio was over the issue of slavery and fugitive slaves, and the complex political situation in which Rosetta found herself fighting for freedom, it

${ }^{41}$ Jonathan Daniel Wells, Blind No More, ch. 1 
is necessary to take a quick look at some of the local politics concerning these issues. This covers both personal liberty politics as well as the formation of pro-slavery politics.

As early as 1780 , northern states began passing anti-kidnapping laws, collectively referred to as Personal Liberty Laws, in response to the fugitive slave issue. The marked divide between the slave holding South and a North which had either gradually or immediately abolished slavery meant that two distinct systems of law developed on either side of the Mason-Dixon line, fueling the fight over state versus federal authority. Southern slavery relied on laws that recognized the right to own people as property, a right which they argued was constitutional. When northern states abolished slavery therefor, they also had to reinterpret a system of laws built up around that institution. The politics of personal liberty are not simply the product of northern abolitionism coming out of an enlightened view on human rights, but were also the product of careful political and legal maneuvering to ensure that northern states would not become unwilling allies to southern slavery. Though abolitionism in states like Pennsylvania, and to a lesser degree Ohio, began to adopt a stance that assumed all African Americans to be free on their soil unless proven otherwise, such radical sentiments rarely made it into law. Northern states were after all tied closely to their southern neighbors through bond of trade, and racist anti-black sentiments were just as common above the MasonDixon line as below it. Anti-kidnapping laws found success when they accepted a position of compromise, with politicians taking the stance that they only wished to see their citizens protected and their laws recognized. Senator Benjamin Wade of Ohio raised the point, "Cannot a sovereign State of this Union prevent the kidnapping of her free citizens because you have a right to claim a slave fleeing from service?"42 Though these laws certainly became a useful weapon against slavery, their primary function was to ensure that a state's local court was recognized by forcing any fugitive case before a judge. Anti-kidnapping laws enforced fines or other punishments for false

42 Thomas D Morris, Free Men All, pg. 1 
kidnappings and otherwise tried to force incidents of seizure into court in order to force the kidnapper to prove that the person they had trapped was in fact a fugitive. ${ }^{43}$

Though northern states could not directly oppose the right to recapture, and many of them including Ohio never showed a unified interest in doing so, they did attempt to mitigate the power of the Fugitive Slave Law by passing laws that would slow the processes of recapture down with the intent of hindering illegal capture and sale of free African Americans. In essence, they wanted to insure the right of habeas corpus in order to give each fugitive an appearance in court. Though initially many northern states attempted to pursue such laws on a federal level, it quickly became apparent that this task was nigh on herculean. Instead, states like Pennsylvania began to formulate anti kidnapping laws that sought to strengthen state power over federal power. The question of whether or not states could pass laws against kidnapping were unquestioned, but whether or not they could do so in a case where it might contradict a federal law were less clear. Therefor, personal liberty politics walked a fine line between asserting state sovereignty and directly undermining the federal government. Though not all northern states adopted anti kidnapping laws of similar fortitude, states like Pennsylvania which directly challenged the Fugitive Slave Law and states like Ohio which only indirectly tried to mitigate it were both accused of challenging law and federal authority by the proslavery camp. ${ }^{44}$

With the passage of the original Fugitive Slave Law in 1793 and the following compromise in 1850, the North saw the South as using the federal government to unjustly encroach on their political rights. But not everyone in the North reacted equally. Any story of abolition in the North can be seen through the lense of those who objected to the institution purely on a moral basis, but it should also be seen through the lense of those who also saw the fight against slavery as a political struggle between North and South. William Lloyd Garrison, an abolitionists and editor of the Boston based newspaper The Liberator, took a radical moral stance that not only was slavery bad, but

\footnotetext{
${ }^{43}$ Hyun Hur, "Radical Antislavery and the Personal Liberty Laws in Antebellum Ohio, 18031857"; Thomas D Morris, Free Men All, ch. 1

44 Thomas D Morris, Free Men All, pg. 25
} 
any law which supported it was corrupt and any citizen that refused to actively challenge such a law was complicit. ${ }^{45}$ Massachusetts Senator Daniel Webster on the other hand, famously compromised his supposed anti slavery position to advocate for order and the salvation of the Union when he weighed in support of the Fugitive Slave Law. ${ }^{46}$ Therefor the emergence of personal liberty politics in the North should not be accepted as a given based on the fact that they had abolished slavery. Instead, they were hard fought for policies that found mixed success across the board. Northern states were not a homogenous society, wholeheartedly committed against the evils of slavery. Despite how invasive the Fugitive Slave Law was, and how much it clearly tipped federal power in the favor of the South and away from the North and individual states, northern responses to the law were not uniform. Especially in states like Ohio, whose population consisted of several generations of white migrants from the South, reactions to slavery were mixed.

Personal liberty politics in Ohio had to be hard fought for, as a large portion of the state resisted them. Ohio saw a significant increase in its free African American population during this time, due in part to the success of the Underground Railroad as well as the draw of jobs, which in turn ignited racist sentiment across the state. Though the Northwest Ordinance of 1787 and the state constitution prohibited slavery in the Northwest Territories, the Black Laws formed not shortly after in 1804 and 1807 proved this was not out of any greater belief in equality. ${ }^{47}$ Racism was a powerful sentiment amongst many white Ohions, and even the Western Reserve, the bastion of abolitionism in Ohio, was not exempt. Many immigrants from New England brought with them a kind of genteel racism that colored the lense through which they approached abolition work with white supremacy. ${ }^{48}$ Underlaying these laws was a fear common to almost any racist ideology, a fear of racial inter marriage, but other arguments helped to

\footnotetext{
${ }^{45}$ Henry Mayer, All on Fire, intro

${ }^{46}$ Thomas D Morris, Free Men All, pg. 135

47 Tom Calarco, Search for the Underground Railroad, pg. 35

48 Hyun Hur, "Radical Antislavery and the Personal Liberty Laws in Antebellum Ohio, 18031857" ch. 1
} 
couch these laws in a veneer of logic. Many white Ohions saw northern resistance to slavery as both a challenge to the Constitution and the sanctity of the Union, as well as a threat to their jobs, which they feared would be taken by free African Americans willing to work for less. ${ }^{49}$ Others also recognized slavery as a source of cheap material for northern industry, and challenged abolition on those economic terms. In several instances in Ohio, these sentiments boiled over and saw entire African American settlements destroyed in fits of racists anger. ${ }^{50}$ Therefor, anytime a fugitive from slavery was able to successfully fight for and win their freedom in a northern state, historians must carefully examine the circumstances around that case and consider every factor that might have influenced its outcome.

Ohio, with its relatively large pro-slavery population, was constantly flip-flopping between anti- and pro-slavery policies, and issued an equal amount of legislation for and against slavery. Though the Northwest Ordinance of 1787 And the Ohio state constitution both outlawed slavery in the region, in 1804 Ohio passed its first Black Law. The law not only required that African Americans hold a certificate of freedom in order to settle in Ohio, but it also clearly enforced Article IV in the US Constitution and the 1793 Fugitive Slave Law by easing the process of recapture. In large part this law was a concession made towards Kentucky and Virginia, whose close business ties with Ohio made a majority of Ohioan politicians eager to keep their southern slaveholding neighbors happy. However, it is also important to keep in mind the powerful proslavery and racists sentiments which persisted in Ohio, especially the southern half of the state, which would have also seen such a law as a means of protecting themselves against the perceived dangers of racial co-mingling, and would have supported such laws regardless. ${ }^{51}$ The 1804 Black Law also required any law enforcement to arrest alleged fugitives and to deliver them up to the claimant, who needed very little evidence to

\footnotetext{
${ }^{49}$ Nat Brandt, Yanna Brandt, In the Shadow of the Civil War: Passmore Williamson and the Rescue of Jane Johnson (Columbia, SC: University of South Carolina Press, 2007) 50 Tom Calarco, The Search for the Underground Railroad, pg 36; ${ }^{50}$ Hyun Hur, "Radical Antislavery and the Personal Liberty Laws in Antebellum Ohio, 1803-1857" pg. 32 51 Hyun Hur, "Radical Antislavery and the Personal Liberty Laws in Antebellum Ohio, 18031857" pg. 41
} 
prove the identity of the individual. Like the national Fugitive Slave Law, it essentially forced individuals to become agents of southern slavery, even if they themselves were either morally or politically against it. Ohio had supposedly outlawed slavery, yet its laws where clearly still in support of it. ${ }^{52}$

The 1804 Black Law was followed by a second one in 1807. As more African Americans moved to Ohio, either as fugitives or free, racist fears in Ohio influenced the passing of this law in order to discourage them from settling in, hoping instead that they would keep moving north towards Canada. African Americans were now required to put down a $\$ 500$ bond as an 'assurance' for their good behavior as well as provide a certificate of freedom. Fines were increased for those who hired African Americans without certificates as well as those who harbored fugitives or obstructed recaptures. Additionally, the law forbade African Americans from giving testimony in court against whites, essentially stripping them of their ability to defend themselves in a legal setting. All of this was done in the name of maintaining the Union and Ohio's good relationship with the South, but it was also a product of the racism that was percolating in the North. ${ }^{53}$

Interestingly enough, the 1804 Black Law was also the first anti kidnapping law in Ohio, as it contained a clause theoretically meant to ensure the safety of Ohio's free African American residents by placing fines on anyone accused of illegal kidnapping. However, this clause was fairly toothless, and has been described as being forged in the interests of Ohio's states rights and not out of regard for its African American residents. Furthermore, the clause was neutralized by the 1807 Black Law. ${ }^{54}$

Ironically, these laws of course helped to fuel abolition work, as kidnappings of free African Americans increased during the same period. The increased kidnappings were caused through a combination of laws, like the Black Laws and the 1793 Fugitive Slave Law which underhandedly encouraged kidnapping by stripping legal protections around free African Americans, but it also had to do with the changing nature of southern

\footnotetext{
52 Ibid, pg. 42

${ }^{53}$ lbid, pg. 44

54 Ibid, pg. 51
} 
slavery. As they became more reliant on the domestic slave trade at the same time that northern demand for southern goods like cotton were growing, it was becoming increasingly worth it to recapture run away slaves or to simply steal new ones from the North. Fueled by these issues and inspired by firebrands such as William Lloyd Garrison in Boston, Ohioan abolitionists began to gather steam. ${ }^{55}$

In 1810, the case of a fugitive named Jane, which caused something of a showdown between the governors of Ohio and Virginia, helped to light this spark of more strident activism. Jane was the slave of Joseph Tomlinson, Jr. in Virginia in 1808, when she was accused of stealing four dollars worth of merchandise and sentenced to death. However, with the help of a sympathetic jailer she was able to make her escape to Ohio, where she not only married and gave birth to a child, but also found employment with a man named Abner Lord. In 1809 Jane's former owner tried to have her recaptured, a process which eventually ended with Jane's forced return to Virginia, though not after a drawn out argument between the Ohio and Virginia state governors as to whose authority was supreme in this instance. In the following years, Ohio politicians slowly began to remove themselves from their predecessors' obligation towards upholding southern slavery and began to resist when their neighbors insisted that Ohio 'do its part' in returning their property. Accordingly, public resistance also grew as crowds, often of mixed race, increasingly gathered to resist the recapture of fugitives. All of this culminated on January 25, 1819 when the state legislature passed an official anti kidnapping law, making the illegal capture of African Americans a misdemeanor. ${ }^{56}$ Though targeted towards protecting free residents, it also helped to protect against the arbitrary seizure of fugitives by formalizing the procedures claimants would have to follow in order to legally remove that person from the state. In front of the right judge, this was the perfect opportunity for the many technicalities and loopholes of the 1793 Fugitive Slave Law to be exploited. ${ }^{57}$

\footnotetext{
55 Ibid, pg. 57; Tom Calarco, The Search for Ohio Underground Railroad, pg. 30

56 Hyun Hur, "Radical Antislavery and the Personal Liberty Laws in Antebellum Ohio, 18031857" pg. 55-64

${ }^{57}$ Ibid, pg. 65
} 
On January 26, 1820, Representative Thomas M'Millan of Wayne County, from the Joint Committee of Revision, introduced a bill to strengthen this law. "An Act To Prevent Kidnapping" would have raised the punishment for illegal kidnapping and included punishment for "enticing' victims away under false pretenses. Most importantly it stipulated that all African Americans should "be presumed and adjudged to be free" and restored African American's right to testify in court against whites. ${ }^{58} \mathrm{Had}$ this bill passed the Senate, Ohio would have had some of the most radical personal liberty laws in the North, and though this bill failed, the belief expressed above would become central to Rosetta's case.

Despite this defeat, the anti-kidnapping law was somewhat strengthened in 1831 , and was also relatively successful at deterring recapture, simply because it made the process more tedious. Yet racism remained a powerful ideology amongst the state's white population. Within this tension, a more radical form of abolition emerged. One which tried to attack discriminatory laws such as the 1804 Black Law head on, by claiming that it was unconstitutional. James G. Birney, the founder of the abolitionists newspaper The Philanthropist, was a leading voice in this movement, and argued that not only was it unconstitutional to force individuals to aid in the recapture of slaves against their will, it was also undeniable that since the state constitution outlawed slavery, all slaves who set foot in Ohio, even with their masters' knowledge and permission, were automatically free. Additionally, he pointed out that since the Fugitive Slave Law denied the writ of habeas corpus, it was by that fact alone not only unconstitutional, but also contrary to the Ordinance of $1787 . .^{59}$

In 1837, the Loraine County Anti-slavery Society passed a resolution asking for the right to jury trial for fugitives, as well as the right for a testimony given by another African American. This was part of a marked shift in tactics, demanding a true legal process in the defense of fugitives, and not just the luck of random circumstances or legal loopholes. Benjamin F. Wade, a radical anti-slavery Whig politician in the Ohio

\footnotetext{
${ }^{58}$ Ibid, pg. 66

${ }^{59} \mathrm{lbid}$, pg. 70; Birney was later the victim of a pro-slavery mob in Cincinnati which destroyed his press in 1836
} 
legislature, argued fiercely for equal rights for African Americans, going beyond merely protecting them from the Fugitive Slave Law. ${ }^{60}$ However, in reaction to this radicalism, by the 1830's, a wave of anti-black sentiment undid much of the progress which had been done, and Ohio once more flip-flopped towards pro-slavery politics.

In reaction to the emergence of a radical anti-abolitionism, whose central tenant was challenging the constitutionality of the Fugitive Slave Law and which was led by such figures as William Lloyd Garrison and locally by Senator Thomas Morris, Ohio passed a Fugitive Slave Law of its own in 1839.61 A bill known as the "Bill of Abominations" by local abolitionists, the law was a direct attack against the anti-slavery movement, which threatened in the eyes of many Ohions, whether they were themselves virulently pro-slavery or simply neutral, to tear the Union apart. The Judiciary Committee in 1837 replied to an abolitionists petition against this bill "...that slave holding states would not have consented to the adoption of the Constitution without a provision authorizing them to reclaim their slaves. Therefor, without regard to individual opinions on slavery and the fictive slave issue, every citizen should respect the constitutional rights of the slave holders in the South." ${ }^{2}$ The state Fugitive Slave Law greatly streamlined the arrest process, firmly involving the state apparatus in reclaiming fugitives on behalf of its southern neighbors. ${ }^{63}$

Though Ohio's Fugitive Slave Law was repealed in 1843, much of the political sentiment which created it remained, especially in the southern part of the state. ${ }^{64}$ However, like a pendulum swinging endlessly back and forth, the abolitionists were in turn fueled by the actions of the anti-abolitionists. The passing of the state Fugitive Slave Law encouraged a more militant and aggressive resistance towards recapture, and abolitionists stepped up their efforts to aid fugitives. ${ }^{65}$ They became even more

\footnotetext{
60 lbid, pg. 73

61 Though a democrat, Morris had come out as very anti-slavery as early as 1836

62 lbid, pg. 76

63 lbid, pg. 80-83

64 Ibid, pg. 18

65 Tom Calarco, The Search for the Underground Railroad, pg. 87
} 
adamant that every fugitive should receive a trial by jury, and did all that they could to see that through.

Several anti-slavery organizations began to form, who fought diligent battles not just in the legal sphere but also on the streets, trying to change public opinion around slavery. Sometimes these fights even got physical. The Ohio Anti-Slavery Society, founded in 1835 as an affiliate of the larger American Anti-Slavery Society founded in 1833, met considerable resistance from Ohions opposed to their beliefs and were forced out of towns and had meetings disrupted with mob violence on several occasions. The abolitionists newspaper, The Philanthropist, based in Cincinnati was attacked and destroyed by a mob twice in January and July of $1836 .{ }^{66}$ But despite resistance there was a fierce abolitionist movement in Ohio. The Ohio Anti-slavery Society continued to publish newspapers and pamphlets in a tireless effort to publicize their ideas and to gather public support for their cause.

When these more official forms of resistance failed, there was also the Underground Railroad, a system which saw hundreds of slaves brought to freedom, either in the United States or all the way to Canada. Udney Hyde was a prominent conductor along the Ohio UGRR in Mechanicsburg. Several of his missions read like something out of a thriller novel, and he often employed a wagon with a false bottom to sneak fugitives right under the nose of slave catchers. ${ }^{67}$ Though Quakers often get the reputation for being abolitionists, Baptists and New School Presbyterians were among some of the other religious groups who became associated with the anti-slavery movement. The reverend Thomas C. Woodson of Quinn Chapel African Methodists Episcopal (AME) Church, who was allegedly the son of Sally Hemmings and Thomas Jefferson, was also a powerful figure amongst the local African American community and a conductor on the UGRR. ${ }^{68}$

66 "Ohio Anti-Slavery Society", Ohio Historical Society, https://ohiohistorycentral.org/w/Ohio_Anti-Slavery_Society

67 Tom Calarco, The Search for the Underground Railroad, pg.119-123

68 Ibid, pg. 40 
Not all UGRR work was church affiliated though. John Hudson, a free African American who was a member of a Gist settlement, a community of free African Americans which had been formed in Brown and Highland County, was singled out as an extremely successful conductor on the UGRR by oral accounts collected after the Civil War. ${ }^{69}$ Everyday citizens, especially free African Americans, also resisted by simply forming crowds and physically interfering whenever they saw someone being accosted by slave catchers. In Boston in 1827, when Seymour Cunningham was confronted by an agent sent by his former master, a multi racial crowd formed around him and challenged the right of the agent. Though he was eventually sold south into slavery, that same crowd gathered $\$ 600$ to buy his freedom. ${ }^{70}$

The atmosphere into which Rosetta's case emerges is thus one of great conflict. Ohio was home both to a militant pro-slavery and anti-slavery movement, who struggled not only for control over the government, but control over the streets as well. Laws were passed and repealed, and mobs were gathered and fought off on both sides. Amongst all of this, African Americans fought on their own terms with the tools at their disposal, even when access to the halls of power was limited to them. White abolitionists, though vital allies that cannot be ignored, worked to forward their own goals as well. Within this context the story of a young sixteen-year-old slave girl who happened to be passing through Ohio in 1855 takes place. While Rosetta's personal courage and the courage of the abolitionists and UGRR workers around her must not be ignored, it was also due to the particular legal and political climate at the time that her case was a success. The judge who saw her case, and politicians in power and the laws being discussed, all must be examined and taken into consideration in order to understand how the story of Rosetta Armstead fits into the a larger narrative about slavery, states rights, and a nation building up to Civil War. ${ }^{71}$

\footnotetext{
$69 \mathrm{lbid}, \mathrm{pg} .36$; Ohio was also home to John Mercer Langston, the first black congressman elected in 1893

70 Jonathan Daniel Wells, Blind No More, pg. 15-16

71 Jonathan Daniel Wells, Blind No More; Samuel May, The Fugitive Slave Law and It's Victims (Cambridge, MA: Harvard University, 1861)
} 


\section{Chapter 3: \\ The Story of Rosetta}

In March of 1855, a sixteen-year-old girl, described as a five foot tall mulatto, named Rosetta Armstead was passing through Ohio, traveling from Virginia to Kentucky. ${ }^{72}$ The former slave of ex-President John Taylor, Rosetta had been bequeathed to President Taylor's son-in-law, the Reverend Dennison (protestant episcopal) of Louisville, Kentucky. Since his wife had recently died, Dr. Dennison intended Rosetta as a nurse for his infant daughter, Betty. ${ }^{73}$ Rosetta was therefor being transported in the company of a good family friend, Doctor Miller, when the state of the river forced them to travel by train. On Saturday, the 10th of March they arrived in Columbus. Since the trains did not run on Sundays, they were forced to stay the night. ${ }^{74}$ This proved to be a life changing stroke of luck for Rosetta, as her presence was quickly noticed by abolitionists and Reverend William B. Ferguson, an African American baptist minister, quickly issued a

\footnotetext{
72 There is some contention around this point. Most newspaper articles from the time suggest that they are on the way to Kentucky, but in the memoir of Levi Coffin (The Reminiscences of Levi Coffin: The Reputed President of the Underground Railroad, 1880), he states that they were on their way from Kentucky to Virginia, though he also says that Rev. Dennison had been living in Louisville, Kentucky for the past three years.

${ }^{73}$ Anti-Slavery Bugle, April 7th, 1855, pg. 1 (The April 7th edition ran a massive story on Rosetta spanning three pages out of four. The Anti-Slavery Bugle would continue to be the most vocal about Rosetta, and will produce several more lengthy articles about her.)

${ }^{74}$ Carrol Free Press April 5th, 1855, pg. 2; Anti-Slavery Bugle September 1st, 1855, pg. 2
} 
writ of habeas corpus on her behalf. ${ }^{75}$ By midnight the sheriff had her in custody and she was on her way to freedom. ${ }^{76}$

Rosetta was brought before Judge Jamison of the Franklin county probate court, where Mr. Galloway, Mr. Warrington, and Mr. Taylor were hired to be her counsel. According to an article in the Carrol Free Press, Rosetta there declared that she wished to be free and was permitted to choose a guardian. Mr Van Slyke was declared her legal guardian and posted her $\$ 300$ bond, as under the 1807 Black Laws she, as an African American wishing to settle in Ohio, was required to post bond as assurance of her good behavior. The decision of Judge Jamison stated that since Rosetta had been brought into Ohio with the full consent of her master, she was not a fugitive and thus on the 12th of March,1855, Rosetta Armstead was free. ${ }^{77}$

However, Rosetta's story was far from over. The same article continues to say that Dr. Dennison visited Rosetta at the residence of Mr. Van Slyke, and had a conversation with her wherein he seemed "much grieved to loose a favored servant.". ${ }^{78}$ An article by the Anti-Slavery Bugle on April 7th describes this conversation in a little more depth, though once again it is from the account of Mr. Van Slyke, and not the words of Rosetta directly. Reportedly Dr. Dennison was very cordial and stated that it was up to Rosetta to decide her fate, though he did press that as a free person she would not be able to go home and "see little Betty", the little girl who she would have become a nurse for. According to Mr. Van Slyke, however, Rosetta firmly declared that she wished to remain free and stay in Ohio. ${ }^{79}$ Though Dr. Dennison's sentiment sounds like a naked farce to our modern ears, it could very well have been a genuine sentiment on behalf of $\mathrm{Dr}$.

\footnotetext{
75 Incidentally, Ferguson is the only named African American person directly involved in Rosetta's case

${ }^{76}$ Carrol Free Press, April 5th, 1855, pg. 2 (The April 5th edition of the Carrol Free Press devoted two whole columns to Rosetta on the second page)

${ }^{77}$ Rosetta Armstead Release From Custody, March 12th, 1855, Ohio History Connection Archive: Digital Collections, Ohio Memory; Carrol Free Press April 5th 1855. pg. 2; Anti Slavery Bugle April 7th, 1855, pg. 1

${ }^{78}$ Carrol Free Press, April 5th. 1855, pg. 2

${ }^{79}$ Anti-Slavery Bugle, April 7th. 1855, pg. 1
} 
Dennison, who like many other southerners could have believed wholeheartedly in the benign nature of slavery. ${ }^{80}$

The next time we hear of Rosetta, her newly won freedom is challenged when she is arrested by Marshal Robinson on the 23rd of March. ${ }^{81} \mathrm{~A}$ newspaper article printed in the Belmont Chronicle on March 29, 1855 details that at the time Rosetta was working for Doctor Coulter, who ran a hydropathic establishment in Columbus and who was also fairly active in the local abolitionists circle. When the doctor received two unnamed visitors, one of them recognized Rosetta and pulled out a warrant for her arrest. Dr. Coulter apparently ran next door to "raise the alarm" while the two men brought Rosetta into custody. Dr. Coulter was not only physically outmatched, one against two, but he was also legally outmatched, as there was no argument he could make in Rosetta's defense other than to alert his fellow abolitionists of her capture. Therefor, he immediately ran to alert his allies, so that they might amass the proper street-level opposition and press accounts needed to turn the tide in Rosetta's favor. Dr Coulter certainly knew that Rosetta would be arrested in his absence, but he made a strategic decision, one which was fairly logical. Amassing large crowds in order to stop or at least slow down an arrest was a common abolitionist practice. In order to insure that the fugitive in question would be able to be brought to court, it was first necessary to insure that the slave catcher didn't simply vanish with their captive in tow. According to one description of events, he was at least partially successful as quiet a large crowd gathered at the train station to watch as Rosetta was loaded on board bound for Cincinnati, with Dr. Ide and Mr. Van Slyke hot on their heels. ${ }^{82}$

The Belmont Chronicle article also reveals how important public opinion was, when it came to generating general support for the cause of fugitive slaves. The editors

${ }^{80}$ Caroline L. Shanks “The Biblical Anti-Slavery Argument of the Decade 1830-1840" The Journal of Negro History, vol. 16, no. 2 (April, 1931), pg. 132-157

${ }^{81}$ Rosetta Armstead Court Transcript, March 26th 1855, Ohio History Connection Archive: Digital Collections, Ohio Memory

82 Ohio State Journal March 28th, 1855; Anti-Slavery Bugle, March 31st, 1855, pg. 3; Belmont Chronicle, March 29th, 1855 ( I was unable to get page numbers for the Ohio State Journal, but the article was a short piece in the March 28th edition) 
emphasized the tragedy, youth, and vulnerability surrounding Rosetta's capture, noting that she was kidnapped in "..a harsh way" and wasn't even given a shawl or a covering of any kind before she was dragged onto the street. The image of a young girl, being roughly and unfairly hauled outside by two men was sure to stir some sympathetic feelings for Rosetta's case. It also reveals how fragile Rosetta's freedom was at that point, that she could so easily be arrested if simply a person with ill intentions recognized her. ${ }^{83}$

Once in Cincinnati, Rosetta was committed to jail in the custody of Marshal Hiram H Robinson. Marshal Robinson was working under a warrant which ordered that she be presented before Commissioner Pendery, who had been appointed by Dr. Dennison to determine his claim, but Rosetta's abolitionists allies once more intervened on her behalf. ${ }^{84}$ According to the court transcripts, on the 26th of March a man named Charles $\mathrm{H}$. Langston petitioned Judge Parker of the court of common pleas in Hamilton county for a writ of habeas corpus on behalf of Rosetta. He claimed that she was being held captive by the Marshal Hiram H. Robinson. A writ of habeas corpus was issued by Judge Parker, and on the 29th of March Rosetta was discharged into the custody of Mr. Van Slyke. It was decided that since she had been declared free by Judge Jamison before the warrant had been commissioned, that her arrest had been unlawful. In response and in support of this decision, Judge Walker stated an opinion that in this case, the rightful supremacy of the Ohio state Constitution was being upheld over the slave laws of Kentucky. ${ }^{85}$

However, shortly after being discharged, Rosetta was once again arrested by the Marshal H. H. Robinson. ${ }^{86}$ Marshal Robinson was still acting on the same warrant,

83 Belmont Chronicle March 29th, 1855, pg. 2

${ }^{84}$ Carrol Free Press April 5th, 1855, pg. 2

${ }^{85}$ Anti Slavery Bugle September 1st, 1855, pg. 2

${ }^{86}$ Rosetta Armstead Petition From L. G. Van Slyke, April 3rd, 1855, Rosetta Armstead Petition from L. G. Van Slyke, March 26th, 1855, Ohio History Connection Archive: Digital Collections, Ohio Memory; Anti Slavery Bugle March 31st, 1855, pg. 2 
which he had received on the 20th of March. ${ }^{87}$ According to the 1850 Fugitive Slave Law, appointed commissioners had jurisdiction over the judges of the circuit and district courts. Legally speaking, in cases of fugitives, the commissioner had final say. However, it had been decided by Judge Jamison and Parker that Rosetta was not only free, but had been brought to Ohio with the full knowledge of her owner, and that therefor she was not and had never been a fugitive. ${ }^{88}$ Thus the warrant under which Marshal Robinson had seized Rosetta was officially void, since she was a free individual and not a fugitive, making the arrest illegal.

A another writ of habeas corpus was petitioned and issued on the 30th of March, commanding Marshal Robinson to deliver Rosetta before Judge Parker on the 31st of March. However he refused, claiming that the warrant he had arrested her under ordered him to deliver her in front of the commissioner. The date for that trial had been adjourned until April 3rd, and Robinson planned on detaining Rosetta until then. ${ }^{89}$ It was eventually decided that since Rosetta had been seized after the court had discharged her, that the accusation of contempt in this case was invalid, and Marshal Robinson continued to hold Rosetta captive. Senator Pugh commented on the case and declared that since Rosetta had been seized after she had been discharged from the court, no act of contempt had been done. ${ }^{90}$

However, the abolitionists were not content to let the situation stand. Since Robinson still refused to release Rosetta, on the 3rd of April, Mr. Van Slyke petitioned the court of common pleas of Hamilton county once more for a writ of habeas corpus commanding that Marshal Robinson produce the body of Rosetta in front of the court. ${ }^{91}$

\footnotetext{
${ }^{87}$ Rosetta Armstead Court Transcript, March 26th 1855, Ohio History Connection Archive: Digital Collections; Hiram H Robinson Habeas Corpus Petition, April 2nd, 1855, Ohio History Connection Archive: Digital Collections

${ }^{88}$ M'Arthur Democrat April 27th. 1855, pg. 1; Fremont Journal April 6th, 1855, pg. 2 (The M'Arthur Democrat offered a front page column on Rosetta)

${ }^{89}$ State of Ohio vs. Hiram H Robinson transcript and judgement, April 2nd, 1855, Ohio History Connection Archive: Digital Collections

${ }^{90}$ Anti Slavery Bugle April 7th, 1855, pg. 3; Spirit of the Times, April 10th, 1855, pg. 3

${ }^{91}$ Rosetta Armstead Petition From L. G. Van Slyke, April 3rd, 1855, Ohio History Connection Archive: Digital Collections
} 
In response, Judge Parker issued a writ of habeas corpus demanding that Marshal Robinson present the body of Rosetta. Ironically enough, since he had previously been cleared of contempt, it was his response to this writ which made that accusation stick and landed the Marshal in jail. ${ }^{92}$ Judge Parker ordered that Robinson be fined $\$ 50$ and committed to jail until he could comply with the court's order..$^{93}$

While in jail, Marshal Robinson petitioned for a writ of habeas corpus himself, and was granted one by Judge McLean of the circuit court, who was known to have strong pro-slavery leanings. ${ }^{94}$ Within his petition, he made no mention of having seized Rosetta a second time after she had been discharged by Judge Parker. Instead he described the events as follows: he received a warrant on the 20th of March, ordering him to arrest Rosetta and bring her before Commissioner Pendery. He did so on the 23rd of March, bringing her before the Commissioner in Cincinnati on the 24th. However, the trial was adjourned as certain individuals could not attend, and was therefor in the mind of Robinson still ongoing when Judge Parker issued his second writ of habeas corpus on the 30th of March, demanding that Robinson deliver Rosetta. This of course ignored the fact that he had seized her a second time after she had been discharged by Judge Parker. ${ }^{95}$

On the 3rd of April, Rosetta did appear before Commissioner Pendery, who, despite his pro-slavery leanings agreed with the previous decisions of both Judge Jamison and Judge Parker and declared Rosetta free, once and for all. ${ }^{96}$ Pendery echoed Judge Parker's ruling, who had stated that, "the moment a slave, with the consent of his master, or in his company, breathes the air of Ohio, his remaining time with that master becomes dependent upon his own will." ${ }^{97}$ This announcement was met

\footnotetext{
${ }^{92}$ Carrol Free Press, April 12th, 1855, pg. 2

${ }^{93}$ State of Ohio vs. Hiram H Robinson transcript and judgement, April 2nd, 1855, Ohio History Connection Archive: Digital Collections

${ }^{94}$ Anti-Slavery Bugle, March 22nd, 1856, pg. 2

${ }^{95}$ Hiram H Robinson Petition for Habeas Corpus, April 2nd, 1855, Ohio History Connection Archive: Digital Collections

${ }^{96}$ Belmont Chronicle, April 5th, 1855, pg. 3 (After their lengthy article on the 29th of March, The Belmont Chronicle only gave short updates on the case)

${ }_{97}$ Anti-Slavery bugle, April 7th, 1855, pg. 1
} 
with cheering from the large crowd, mostly African Americans, which had gathered to watch the proceedings, and which reportedly followed Rosetta and Mr. Van Slyke all the way back to the Woodruff House where they stayed for the duration of their time in Cincinnati. ${ }^{98}$

The case was declared a victory by abolitionists. An instance where the rightful supremacy of the Ohio state Constitution triumphed over the slave laws of Kentucky. Rosetta returned to Columbus with Mr. Van Slyke, where she was reportedly met with a sizable crowd and applause at the train station. ${ }^{99}$ In the Anti-Slavery Bugle, Judge Parker was mentioned as attending a anti-slavery convention and was commended for his decision on the Rosetta case. ${ }^{100}$ Mr. Van Slyke was presented with a silver plate. ${ }^{101}$ The last we hear of Rosetta, she is heading for New England, where reportedly a wealthy lady who had witnessed her case and had decided to take her in and offer her an education at the local seminary school. ${ }^{102}$ Commissioner Pendery and Marshal Robinson would go on to be involved in another case involving habeas corpus and accusations of contempt in the infamous story of the fugitive slave Margaret Garner and her children. ${ }^{103}$

Throughout the duration of Rosetta's case and well into April, a fierce discussion was generated as local newspapers printed story after story commenting on the case, pulling out sensational quotes and offering up their own two cents about whether or not the law had been rightfully upheld in this instance. An article in the Carrol Free Press on April 5th quoted Senator Pugh as saying that, "The seizure of the girl by the Marshal, on the warrant of the U.S. Commissioners after such warrant was declared by a competent tribunal defective, brings up the question of jurisdiction between the $U$. States and the State of Ohio." 104 This comment, which was echoed by several other

\footnotetext{
98 Daily Ohio Statesmen, March 31st, 1855

${ }^{99}$ Cadiz Democrat, April 11th, 1855, pg. 2; Carrol Free Press, April 12th, 1855, pg. 2

100 Anti-Slavery Bugle, May 26th, 1855, pg. 3

101 Anti-Slavery Bugle, August 4th. 1855, pg. 3

102 Anti-Slavery Bugle May 5th, 1855, pg. 3; Carrol Free Press, April 26th, 1855, pg. 2; Meigs, May 1st, 1855, pg. 2

103 Anti-Slavery Bugle March 15, 1856, pg. 2

${ }^{104}$ Carrol Free Press April 5th, 1855, pg. 2
} 
figures involved in the case, cements how important the question of state power versus federal power was in this case. At the same time that the fate of a sixteen-year-old girl was being decided, so to was the fate of law in the U.S., and whether and when the state law should triumph over the federal law.

In the eyes of of Dr. Dennison and his pro-slavery allies, the outcome of this case was a clear challenge to their federally-protected right to property as understood under the Fugitive Slave Law. Judge McLean, who had released Marshal Robinson under the 1973 Fugitive Slave Law, was clear to point this out. In his decision, Judge McLean made it clear that he did not recognize the authority of Ohio's state laws, nor her courts, to undermine the authority of the federal law. He directly questioned Judge Parker's decision to grant Rosetta the right of habeas corpus, and claimed that Marshal Robinson was fully empowered by law to refuse the commands of the court. A year later the Anti-Slavery Bugle would publish a scathing piece about Judge McLean claiming that he was "preparing the way for slavery" in Ohio and that his decision in the Rosetta case clearly trampled state sovereignty underfoot by affirming the supremacy of a slave commissioner's warrant over the process of the state courts. Though in Rosetta's case his decision did not affect her freedom, Judge McLean's words reveal the central fault line which was running underneath her case the whole time. The question of state authority versus federal power was the fuel that fed the issue of fugitive slaves into such a blaze. ${ }^{105}$ The Fugitive Slave Law, after all, directly undermined not only the authority of the northern states who were opposed to slavery, but it also undermined the authority of the courts. Dr. Dennison's attorney, Mr. Wolfe, insisted that the court had no power to liberate slaves and challenged Judge Parker, saying, "Your Honor is sworn to to support the U.S. Constitution, and that is supreme.". ${ }^{106}$ According to the Fugitive Slave Law, no court, not even the supreme court, could go against the a warrant written for a fugitive slave, yet by claiming that Rosetta was not a fugitive, since she had never run away but

${ }^{105}$ Ex Parte Robinson \{6 McLean, 355; 3 Li v. Law Mag. 386\} April term, 1855, law.resource.org https://law.resource.org/pub/us/case/reporter/F.Cas/0020.f.cas/0020.f.cas.0969.pdf; Carrol Free Press, April 12th, 1855; Anti-Slavery Bugle, March 22nd, 1856

${ }^{106}$ Anti-Slavery Bugle, April 7th, 1855, pg. 2 
had been brought to Ohio with the full consent of her master, Judge Parker effectively skirted around the entire issue by claiming that the Fugitive Slave Law had no jurisdiction in this case. Essentially, by declaring Rosetta free, he was affirming the authority of the state of Ohio, and her courts.

This decision was by no means a foregone conclusion. The supreme court case Prigg v. Pennsylvania in 1842, involving a fugitive by the name of Margaret Morgan just a few years prior had decided almost the complete opposite. ${ }^{107}$ Margaret Morgan was a runaway slave from Maryland when she was found and arrested in Pennsylvania by Edward Prigg, who was acting on behalf of her owner, Margaret Ashmore. According to Pennsylvania's Personal Liberty Laws, which were some of the oldest in the country,

....any person shall, by force and violence, take and carry away, or shall by fraud or false pretense attempt to take, carry away, or seduce any negro or mulatto from any part of the Commonwealth, with a design or intention of selling and disposing of, or keeping or detaining, such negro or mulatto as a slave or servant for life, or for any other term whatsoever, such person, and all persons aiding and abetting him, shall, on conviction thereof, be deemed guilty of a felony, and shall forfeit and pay a sum not less than five hundred nor more than three thousand dollars, and shall be sentenced to undergo a servitude for any term or terms of years not less than seven years nor exceeding twenty-one years, and shall be confined and kept at hard labor, etc. ${ }^{108}$

Thus, by the law of the state, Prigg had seized Margaret unlawfully. The case was contested all the way to the supreme court, where it was ruled that despite the strength of Pennsylvania's state law, on this subject it would be forced to bow to the power of the federal Constitution, and it was decided that a warrant written for the recovery of a

107 Steven Lubet, Fugitive Justice; Surprisingly enough, this incident bears some resemblance to Rosetta's case, and an article in the Anti-Slavery Bugle on September 1st, 1855 even mentioned that Judge Parker's decision was in direct conflict with that which had been decided in Prigg V. Pennsylvania. Though Rosetta was not a fugitive in the sense that she had run away, Margaret Morgan, the fugitive in question during Prigg V. Pennsylvania, was living in a free state as a free woman when she was arrested, much like Rosetta when she was arrested in Columbus.

108 Thomas D Morris, Free Men All, pg. 42-59 
fugitive slave could not be challenged by any law in the state in which the fugitive was apprehended.

According to this case, it was "Historically well known" that the Constitution promised to "secure to the citizens of the slaveholding States the complete right and title of ownership in their slaves as property in every State in the Union into which they might escape from the State where they were held in servitude." This belief was certainly held by Dr. Dennison, and his slave owning compatriots in Kentucky who made such an outcry at his loss. ${ }^{109}$ On the 31 st of March, while the motion to arrest marshal Robinson was being decided, Dr. Dennison who was present testified that he was only following the law and that he "...represents a large body of union loving citizens." ${ }^{110}$ His emphasis on "union loving citizens" suggests that some in the South understood the North as the true disrupters of peace. In their eyes, it was the abolitionists who wished to tear apart the Nation, not the South. Slavery was protected by the Constitution, and furthermore it represented the proper rule of federal law and followed the natural course of civilization. All of this was threatened when the judges involved in Rosetta's case blatantly stated that by Ohio's law, she was not a fugitive and therefor free. They were asserting not only the laws of their state, but also a drastically different interpretation of the Constitution and its power over individual states.

The accusation of contempt against Robinson and Dennison's loss of property caused a massive uproar in Kentucky. ${ }^{111}$ The Fremont Journal quoted from the Louisville Times, stating that Col. Hodge of Kentucky vowed to bring the whole of the South down on Ohio should the two not be found innocent. The Belmont Chronicle reported rumors that a large party of men was being gathered to forcefully bring Rosetta back to Kentucky. ${ }^{112}$ The Anti-Slavery Bugle reported that southern papers were outraged, crying that a Kentuckian had had his property wrested away from him, despite having the full protection of the U. S. Constitution. It was claimed that abolitionism, "....if

\footnotetext{
109 J. Blaine Hudson, Fugitive Slaves and the Underground Railroad in the Kentucky Borderlands(North Carolina: McFarland and Company, Inc., 2006), pg. 141-143

${ }^{110}$ Anti-Slavery Bugle, April 7th, 1855, pg. 2

111 Anti-Slavery Bugle, April 14th, 1855, pg. 3

112 Fremont Journal April 6th, 1855, pg. 2; Belmont Chronicle, April 5th, 1855, pg. 2
} 
not thwarted early, will assail us at our very doors, and bury the knife of the assassin in the hearts of our innocent families...Are we to become an enslaved race ourselves, with Northern masters?" 113 Of course, nothing ever came of these grand speeches, but they serve to highlight the growing divides between North and South. The sentiment expressed above echoes the same claims that Senator Mason made when pushing for the 1850 Fugitive Slave Law, stating that the Nation had a duty to protect southern slavery, and that strong laws were needed to ensure that the North did not break that promise and threaten the very bedrock of southern society. ${ }^{114}$

But the South was not the only one to feel threatened. The Anti-Slavery Bugle stated, even as they celebrated the success of Rosetta's case, that, "the people of this Nation should be aware that there is a systematic and general effort now in progress to establish slavery by judicial decisions and forms of law...in the nominally free states."115 This shows that similar to how the South saw a insidious plan to undermine their slave owning right, the North also saw a looming threat to their values. Abolitionists in particular felt that the Nation was being subsumed under the will of the slave owning South. In an article from the New York Times describing the case of Robinson v. Ohio, judge Walker was quoted at length, and made it very clear in which framework he saw the proceeding events. In an impassioned speech he cried, "Sir, are we men or are we boys? Is the contempt the less because committed in the manner it was? I regard it not only contempt, but as a most aggravated one. Can the Marshal thus place the decision of the court at defiance, without committing contempt? Are we, in view of these announcements, solemnly made, to knuckle to such demands or yield to such threats? Is there a north? Is there a state of Ohio? If there are, then, in God's name, let them be evidenced." ${ }^{116}$ His words shine a dramatized light on a core issue, the identity of the state of Ohio. Abolitionists and those sympathetic to their cause saw the fight against slavery not only as a chance to make a moral stand but also to assert the power of local

\footnotetext{
${ }^{113}$ Anti-Slavery Bugle, April 21st, 1855, pg. 3

114 Steven Lubet, Fugitive Justice

${ }^{115}$ Anti-Slavery Bugle September 1st, 1855, pg. 2

${ }^{116}$ New York Times, April 2, 1855, pg. 1
} 
laws and of state sovereignty, here glossed and naturalized as "real men." For Ohio to bow to the authority of the federal Fugitive Slave Law, and the slave owning South by extension, would subsume what abolitionists were framing as a core tenet of Ohio, their politics of free soil. Judge Walker saw this as an opportunity to assert the position of the state of Ohio in regards to said struggle. Rosetta, for him, was not just a sixteen-yearold girl in need of help, she was also an opportunity to articulate his stance on the fight between the states over an issue not of slavery, but of rights.

Rosetta's story reveals the legal and political context of the fugitive slave debates, but it also highlights the fragile existence of African Americans in the border states. Though she had been declared free by the court and was not only living with a legal guardian but also gainfully employed, all it took was being recognized and antagonized by a proslavery activists for her to be thrust back into the struggle for freedom. The fact that Rosetta was arrested twice, and both times declared free, is remarkable. That she was declared free by the very commissioner who had issued the warrant for her arrest is even more so. If circumstance had put Rosetta in a different court or in a different state, the ruling might have been very different. For even under the 1850 compromise, the power of the law was still tilted in the favor of the South. Judge Parker's ruling, which was questioned by Judge McLean, could have very easily been challenged.

In the case of Jerry Phinney, he had the bad luck of running into a Columbus Justice who was less than sympathetic to the fugitive cause. Justice William Henderson helped to organize the kidnapping of Phinney in 1846 despite the fact that Phinney had been living as a free African American for fifteen years. ${ }^{117}$ Unlike Rosetta, who had the good luck to come before a sympathetic judge, Phinney's mistake was coming into contact with those who chose to enact the federal law against him instead of the local laws for him. In another case very similar to Rosetta, a man walked away from his master after learning that since slavery was illegal in Ohio, he was now a free man. But lacking the aid of local abolitionist, he was eventually caught and sold further down south. ${ }^{118}$ Herein

\footnotetext{
117 Tom Calarco, The Search for the Underground Railroad, pg. 108
}

118 Jonathan Daniel Wells, Blind No More, pg. 36 
lays one of the difficulties in studying the history of fugitive slaves, how to balance between the agency of the individual and the courage and fortitude they had to make the attempt to escape, and yet the undeniable need for allies which made a massive difference for their chances of success. It is important to give both the fugitive and the abolitionists their due, and balance their respective work in any single case.

\section{Conclusion: Rosetta Beyond the Question of Slave, Fugitive or Free}

I do not consider Rosetta's case to be unique. Certainly, there are other cases which drew much more attention with their drama and their action packed events. But neither is Rosetta's case ordinary. In fact, I would argue that there is no such thing as an ordinary fugitive slave case, as each one was filled with so many variables that affected their outcome, many of them out of the hands of the people directly involved, that to claim that there was any such this as a 'standard' fugitive slave case seems a 
gross oversimplification of the entire situation to me. Rosetta's story offers an opportunity to observe the case of a fugitive slave and how it became a fulcrum around which multiple interests revolved. This is not so much Rosetta's story as it is the story that was told around her. When we look at the actions of the people involved in her case, those who aided her and those who tried to recapture her, we can begin to see the ways in which power worked around the issue of slavery. We see how both proslavery and anti-slavery interests met in a careful battle that not only contested the law, but the social and political contentions around slavery as well. Rosetta's case challenged the legality of slavery, but the general uproar around her case also revealed how these issues were presented and received in the cultural parlance of the time.

It is tempting to read this story as a clean win for the abolitionists in Ohio, as an instance of good winning out against bad, but as is always the case in history, a finer observation of the tale reveals how subtle political mechanizations made this not a story of morality but of politics, and of how a sixteen year old girl became a catalyst therefor. Thus this is also the story of how personal quests for freedom interact with larger, more symbolic quests for symbolic freedoms. How fugitive slaves, for whom the issue of freedom was extremely personal, interacted with abolition societies and white allies, for whom freedom was a larger, more political issue.

As brave and harrowing as their stories are, it is important to place the actions of individuals within the context of politics at the time, politics which were largely dominated by whites and therefore riddled through with their own agendas even when ostensibly the issue was around slavery. ${ }^{119}$ Rosetta, as an African American sixteenyear-girl, was an incredibly brave individual to take the leap and take the chance at freedom which was offered her, but she was also surrounded by people who had considerably more political agency then she did, and whose interests and agendas shaped her experience beyond a doubt. The case of Rosetta Armstead also illuminates how the Fugitive Slave Law simultaneously succeeded and failed due largely to the

\footnotetext{
119 Some politicians fought for the right of African Americans to petition but were often firmly shut dow. Thus without the power to vote or petition, Africans Americans had to wither make their own protections or rely on white allies who could access the halls of power
} 
machinations of local power interests, both aided and hindered by state laws. It illuminates the importance of the actions of individuals, and therefore serves as a remainder that as historians, we must always juggle the abstract and the concrete, the individual and the institution. ${ }^{120}$

This had been primarily a discussion of how the case of Rosetta Armstead reflects and highlights the legal and political struggles that were intrinsically tied into the issue of slavery during the antebellum period. I have discussed how a sixteen-year-old African American girl won her freedom, but as a symbol within the context of a much larger struggle that was predominately being carried out by white men. In large part, this has been a discussion about how white men engaged with abolition work partially out of a moral standing but also largely out of a political interest in state power. However, I also want to emphasize that Rosetta represents so much more than just the story of the politics of fugitive slaves. I would therefor like to end my discussion of Rosetta Armstead by highlighting some essential details in her case, which due to practical restraints I was not able to grant full attention to in this paper.

It is important to remember that there is a very large chance that Rosetta had no idea of the laws in Ohio which eventually granted her her freedom. Many slaves in the South were purposefully fed falsified stories about the North in order to dissuade escape attempts. Had she not been discovered by the abolitionists, it is very likely that she would not have attempted to escape or pursue a legal defense. ${ }^{121}$ It is tempting therefor to see Rosetta's win as a mere happenstance of fate. That she was lucky to happen to be in the right place in the right time. I have already discussed how the successful variables in her case were largely due to the people she encountered, and could have very easily gone very differently. However, I do not wish to depict Rosetta as a passive observer in her own story. Therefor, the first detail is the question of choice and what it means in this context.

120 Joseph C Miller, The Problem of Slavery as History

${ }^{121}$ Levi Coffin, Reminiscences of Levi Coffin, the Reputed President of the Underground Railroad, (Oxford, UK: Oxford University, 1880) pg. 554-557 
If I had more time and another twenty pages I would devote a whole chapter to this question, as it is I will content myself with a brief discussion. Several articles and even some of the legal documents describing the event assume a certain degree of choice on Rosetta's behalf. Judge Parker states in his decision that since coming to a free soil state, that Rosetta's slave status is entirely her decision. ${ }^{122}$ An article in the Daily Ohio Statesmen describing the case waxes poetically about how when a master and slave leave the sphere which decided their status they must stand as equals. ${ }^{123}$ However, since Rosetta's voice is never heard directly in any of the documents pertaining to this case, these statements seem more dramatic expressions than clear evidence that Rosetta's opinion was truly the deciding factor of the matter. Rather, I think it is vital that her whole story is read with the remainder that her every action and word are being transcribed through the actions and voices of those around her. People who coincidently had a great deal more power than she did. This in no way robs her of desire or bravery, at some point she certainly made the decision to pursue her freedom and cooperate with the abolitionists, but the distinct lack of her voice is something which I think needs to be kept in mind.

Stephanie Camp in her book Closer to Freedom: Enslaved Women and Everyday Resistance in the Plantation South articulates the difficulties historians face when interpreting the little acts of resistance which enslaved people might practice. Camp discusses how important it is to understand enslaved people as complex individuals who acted and made decisions based on a complex combination of factors. When discussing agency and the extent to which Rosetta had it while she was going through the Ohio court system, thinking about other ways in which enslaved people expressed agency through acts of resistance as small as dragging their feet can provides a subtle language to dissect Rosetta's own actions, and allows a partial recovery of her voice. ${ }^{124}$

\footnotetext{
122 Anti Slavery Bugle, April 7th, 1855, pg. 1

${ }^{123}$ Daily Ohio Statesmen, March 31st, 1855

${ }^{124}$ Stephanie Camp, Closer to Freedom: Enslaved Women and Everyday Resistance in the Plantation South, (North Carolina: University of North Carolina Press, 2005)
} 
Barbara Bennet Woodhouse, in her book Hidden in Plain Sight: The Tragedy of Children's Rights from Ben Franklin to Lionel Tate, dedicates a whole chapter to the daughters of Dred Scott. Woodhouse describes how the intersection of race and gender have conspired to obscure not only Harriet, Dred Scott's wife, but his two daughters, Eliza and Lizzie as well. Like Rosetta in 1855, Eliza would also become a catalyst for the issue of slavery, when her birth on 'free soil' forced the supreme court to "reach deep into the heart of the controversy and hold that Americans of African descent, whether free or enslaved, were simply not citizens.". ${ }^{125}$ And perhaps also like Rosetta, Eliza found a way to assert agency, even when political and legal power were far outside of her reach. Woodhouse describes how within the limiting context of her situation, the sixteen-year-old Eliza and her eight-year-old sister "made their own world" by temporally running away in 1853 while their father's case was pending. Despite the fact that both the law and the accepted gender norms of the time subsumed their identity to their father's, these two girls found a way to express agency. Woodhouse's handling of this incident helps to define ways in which agency can be recovered, even when the voice of the individual in question cannot be heard directly within the historical narrative. ${ }^{126}$

The second detail I wish to draw out is how gender shows up in Rosetta's case. Though in many ways her gender is ignored in that it grants her no particular consideration one way or another in terms of the legal arguments that helped win her freedom, however there are subtle ways in which it does appear which make it a worthwhile topic to consider. When the Belmont Chronicle describes Rosetta's initial arrest, I would argue it takes her out of a 'black female' identity and temporally grants her a 'white female' identity. The stereotype of the "inappropriate women", as pointed out by W. E. D. Dubois, is one which denied African American women the moderate protection granted to white women and their assumed modesty and "appropriate"

\footnotetext{
125 lbid, pg. 81

${ }^{126}$ Barbara Bennet Woodhouse, Hidden in Plain Sight: The Tragedy of Children's Rights from Ben Franklin to Lionel Tate, (Princeton, NJ: Princeton University Press, 2008), ch. 4
} 
feminine behavior. ${ }^{127}$ Her lack of shawl and bonnet become great tragedies because she is female, but stereotypically feminine in the sense that white women are fully deserving of protection and social courtesy from white men. It is therefor 'inappropriate' that she be dragged out into the public without the proper protections accorded to her gender. Though subtle, this is perhaps a dramatical technique to imply a free identity onto Rosetta. By granting her the identity, if only obliquely, of a 'delicate' female rather than a working class or African American female, she becomes associated with white connotations of gender rather than 'black' connotations of gender. Through this comment she not only becomes a women, but a free women as well. The 'separate sphere's' notion, which was a prevailing ideology in Antebellum America, was also a deeply racist ideology. White women were granted the confines but also the protections of the domestic sphere, while African American women, both free and enslaved, were expected to supply labor on parr with their male counterparts, at the same time that their gender placed them within an extremely vulnerable position within the intersection of race, gender, poverty, and bondage, an intersection which has only recently become a subject of academic study and which at the time would have been very much overlooked.To assume that Rosetta should have been automatically granted the 'modest' protection of a shawl and bonnet implies an elevation in her status. Taking an intersectional approach to Rosetta's case in order to consider how not only her race but also her gender and age affected her experience might prove a worthwhile endeavor further down the road. ${ }^{128}$

${ }^{127}$ Maxine Baca Zinn, Bonnie Thornton Dill, ed, Women of Color in U.S. Society, (Philadelphia, PA: Temple University Press, 1994) ch. 14

${ }^{128}$ Linda K Kerber, "Separate Spheres, Female Worlds, Women's Place: The Rhetoric of Women's History." The Journal of American History, vol 75, no. 1 (June, 1988)

; Kimberle Crenshaw "Demarginalizing the Intersection of Race and Sex: A Black Feminist Critique of Antidiscrimination Doctrine, Feminist Theory and Antiracist Politics." University of Chicago Legal Forum: vol. 1989: Iss. 1, Article 8.; Jane E Dabel "'My Ma Went to Work Early Every Mornin': Color, Gender, and Occupation in New Orleans, 1840-1860" Louisiana history: The Journal of the Louisiana Historical Association, vol. 41, no. 2 (Spring, 2000), pg. 217-229 


\section{Bibliography:}

\section{Primary Sources:}

\section{Newspapers:}

- Anti-Slavery Bugle. (New-Lisbon, Ohio), March 31st, 1855

- Anti-Slavery Bugle. (New-Lisbon, Ohio), April 5th, 1855

- Anti-Slavery Bugle. (New-Lisbon, Ohio), April 7th, 1855

- Anti-Slavery Bugle. (New-Lisbon, Ohio), April 14th, 1855 
- Anti-Slavery Bugle. (New-Lisbon, Ohio), April 21st, 1855

- Anti-Slavery Bugle. (New-Lisbon, Ohio), May 5th, 1855

- Anti-Slavery Bugle. (New-Lisbon, Ohio), May 26th, 1855

- Anti-Slavery Bugle. (New-Lisbon, Ohio), April 28th, 1855

- Anti-Slavery Bugle. (New-Lisbon, Ohio), August 4th, 1855

- Anti-Slavery Bugle. (New-Lisbon, Ohio), September 1st, 1855

- Anti-Slavery Bugle. (New-Lisbon, Ohio), March 15th, 1856

- Anti-Slavery Bugle. (New-Lisbon, Ohio), March 22nd, 1856

- Belmont Chronicle. (St. Clairsville, Ohio), March 29th, 1855

- Belmont Chronicle. (St. Clairsville, Ohio), April 5th, 1855

- The Cadiz Democratic Sentinel. (Cadiz, Ohio), April 11th, 1855

- Carrol Free Press. (Carrollton, Ohio) April 5th, 1855

- Carrol Free Press. (Carrollton, Ohio) April 12th, 1855

- Carrol Free Press. (Carrolton, Ohio), April 26th, 1855

- Daily Ohio Statesmen. (Columbus, Ohio), March 30th, 1855

- Daily Ohio Statesmen. (Columbus, Ohio), March 31st, 1855

- Fremont Journal. (Fremont, Sandusky County, Ohio), March 30th, 1855

- Fremont Journal. (Fremont, Sandusky County, Ohio), April 6th, 1855

- M'Arthur Democrat. (McArthur, Vinton County, Ohio), April 13th, 1855

- M'Arthur Democrat. (McArthur, Vinton County, Ohio), April 27th, 1855

- Meigs County Telegraph. (Pomerory, Ohio) March 27th, 1855

- Meigs County Telegraph. (Pomeroy, Ohio), May 1st, 1855

- New York Times. (New York, New York), April 2nd, 1855

- Ohio State Journal. (Columbus, Ohio), March 28th, 1855

- Spirit of the Times. (Ironton, Ohio, April 17th, 1855

- Spirit of the Times. (Ironton, Ohio), April 10th, 1855 
- True American. (Steubenville, Ohio), April 5th, 1855

- Western Reserve Chronicle. (Warren, Ohio), April 18th, 1855

- Western Reserve. (Warren, Ohio), April 30th, 1856

\section{Legal Documents:}

- Ex Parte Robinson \{6 McLean, 355; 3 Li v. Law Mag. 386\} April term, 1855, law.resource.org https://law.resource.org/pub/us/case/reporter/F.Cas/0020.f.cas/0020.f.cas.0969.pdf

- Hiram H Robinson Petition for Habeas Corpus, April 2nd, 1855, Ohio History Connection Archive: Digital Collections

- State of Ohio vs. Hiram H Robinson transcript and judgement, April 2nd, 1855, Ohio History Connection Archive: Digital Collections

- Rosetta Armstead Petition From L. G. Van Slyke, April 3rd, 1855, Ohio History Connection Archive: Digital Collections

- Rosetta Armstead Court Transcript, March 26th 1855, Ohio History Connection Archive: Digital Collections;

- Hiram H Robinson Habeas Corpus Petition, April 2nd, 1855, Ohio History Connection Archive: Digital Collections

- Rosetta Armstead Release From Custody, March 12th, 1855, Ohio History Connection Archive: Digital Collections, Ohio Memory

- Member Of The Philadelphia Bar. A history of the trial of Castner Hanway and others, for treason, at Philadelphia in November, . With an introduction upon the history of the slave question. Philadelphia, U. Hunt \& sons, 1852. Pdf. https://www.loc.gov/item/44019568/.

- Prigg v. Pennsylvania, 41 U.S. 16 pet. 539539 (1842)

- Somerset V. Stewart (1772) 98 ER 499 


\section{Secondary Sources:}

- Blackett, R.J.M. The Captive's Quest for Freedom: Fugitive Slaves, The 1850 Fugitive Slave Law and the Politics of Slavery. Cambridge, UK: Cambridge University Press, 2018

- Blackett, R.J.M. Making Freedom: The Underground Railroad and the Politics of Slavery. Chapel Hill, NC: University of North Carolina University Press, 2013

- Brandt, Nat., and Brandt, Yanna. In the Shadow of the Civil War: Passmore Williams and the Rescue of Jane Johnson. Columbia, SC: University of South Carolina Press, 2007

- Calarco, Tom. The Search for the Underground Railroad in South Central Ohio. Charleston, South Carolina: The History Press, 2018

- Camp, Stephanie. Closer to Freedom: Enslaved Women and everyday Resistance in the Plantation South. Chapel Hill, NC: University of North Carolina Press, 2005

- Carsel, Wilfred. "The Slaveholders' Indictment of Northern Wage Slavery." The Journal of Southern History, vol. 6, no. 4 (November, 1940)

- Coffin, Levi. Reminiscences of Levi Coffin, the Reputed President of the Underground Railroad. Oxford, UK: Oxford University, 1880. Digital copy R. Clarke \& Company, December, 2006. Accessed May 22nd, 2020. https://www.google.com/books/edition/ /KXUFAAAAQAAJ?hl=en

- Crenshaw, Kimberle. "Demarginalizing the Intersection of Race and Sex: A Black Feminist Critique of Antidiscrimination Doctrine, Feminist Theory and Antiracist Policy." University of Chicago Legal Forum: vol. 1989: iss. 1, article 8.

- Dabel, Jane E. “'My Ma Went to Work Early Every Mornin': Color, Gender, and occupation in New Orleans, 1840-1860." Louisiana History: The Journal of the Louisiana Historical Association, vol. 41, no. 2 (Spring, 2000) 
- Gregory, Anthony. The Power of Habeas Corpus in America: From the King's Prerogative to the War on Terror. Oakland, CA: The Independent Institute, 2013

- Hudson, J Blaine. Fugitive Slaves and the Underground Railroad in the Kentucky Borderlands. North Carolina: McFarland \& Company, Inc, 2006

- Hur, Hyun. "Radical Antislavery and Personal Liberty Laws in Antebellum Ohio, 18031857." Phd Dissertation, University of Wisconsin-Madison, 2012. Accessed May 22, 2020.

https://depot.library.wisc.edu/repository/fedora/1711.dl:7N6CIPCTJADPD8H/datastrea $\underline{\mathrm{ms} / \mathrm{REF} / \mathrm{content}}$

- Kerber, Linda K. “Separate Spheres, Female Worlds, Women's Place: The Rhetoric of Women's History." The Journal of American History, vol 75, no. 1 (June, 1988)

- Lubet, Steven. Fugitive Justice: Runaways, Rescuers, and Slavery in Trial. Cambridge, MA: Harvard University Press, 2010

- May, Samuel. The Fugitive Slave Law and Its Victims. Cambridge, MA: Harvard University Press, 1861

- Mayer, Henry. All On Fire: William Lloyd Garrison and the Abolition of Slavery. New York: W.W. Norton \& Company, Inc, 2008

- Miller, Joseph C. The Problem of Slavery as History. New Haven, CT: Yale University Press, 2012

- Morris, Thomas D. Free Men All: The Personal Liberty Laws of the North, 1780-1861. Baltimore: John Hopkins University Press, 1974

- Shanks, Caroline L. "The Biblical Anti-Slavery Argument of the Decade 1830-1840." The Journal of Negro History, vol. 16, no. 2 (April, 1931)

- Wells, Jonathan Daniel. Blind No More: African American Resistance, Free Soil Politics, and the Coming of the Civil War. Athens, Georgia: The University of Georgia Press, 2019

- White, Deborah Gray. Ar'n't I A Women? Female Slaves in the Plantation South, revised edition. New York: W.W. Norton \& Company, 1999. 
- Woodhouse, Barbara Bennet. Hidden in Plain Sight: The Tragedy of Children's Rights From Ben Franklin to Lionel Tate. Princeton, NJ: Princeton University Press, 2008

- Zinn, Maxine Baca., and Dill, Bonnie Thornton, ed. Women of Color in U.S. Society. Philadelphia, PA: Temple University Press, 1994

\section{Websites:}

- "Ohio Anti slavery Society", Ohio Historical Society, https://ohiohistorycentral.org/w/Ohio_Anti-Slavery_Society

- "Fugitive Slaves: Fugitives From Labor" National Archives, accessed May 19th, 2020, https://www.archives.gov/education/lessons/fugitive-slaves.html

- "Article IV, Section 2: Movement of Persons Throughout the Union" Interactive Constitution, accessed may 19th, 2020, https://constitutioncenter.org/interactiveconstitution/interpretation/article-iv/clauses/37

- "A Century of Law Making for a New Nation: U.S. Congressional Documents and Debates, 1774-1875" American Memory: The Library of Congress accessed May 19th, 2020, http://memory.loc.gov/cgibin/ampage?collld=Ilac\&fileName=003/llac003.db\&recNum=702;

- "To Pass S. 42, An Act Respecting Fugitives From Justice and Persons Escaping From The Service of Their Masters." GovTrack, accessed May 19th, 2020, https://www.govtrack.us/congress/votes/2-2/h85 
